\title{
THE STATUS OF STATE CIVIL APPARATUS COMMISSION IN STATE SYSTEM OF INDONESIA
}

\author{
By : \\ Desi Susanti, Edra Satmaidi, Ardilafiza
}

\begin{abstract}
Along with the formation of institutions in Indonesia, it is known by the term Non-Departmental Government Institutions (LNDP) which after the enactment of the Law on State Ministries which changed department term into ministry, but at the initiative of several ministries, there were also other terms that were introduced, namely Non-Structural Institutions $(L S N)$. One of the NonStructural Institutions $(L S N)$ currently is State Civil Apparatus Commission. In Article 1 number 19 of Law Number 5 of 2014 concerning State Civil Apparatus is stated that the Commission of $A S N$, which abbreviated as $K A S N$, is a non-structural institution which independent and free from political intervention to create $A S N$ employee that professional and performs to provide services fairly and neutral and become adhesive and unifier of the nation. $K A S N$ was formed to supervise the implementation of basic norms of the ethic code and behavior code of $A S N$ as well as the Application of the Merit System in $A S N^{\prime}$ s policy and management.
\end{abstract}

Keywords: Non-Departmental Institutions, State Institution, Independent Institution 


\section{A. INTRODUCTION}

\section{Research Background}

The formation of the State Civil Apparatus Commission is one of the efforts conducted by the government in the framework of bureaucratic reform, this is done because during the new order, the bureaucracy was built to strengthen the ruler, great power plus the ability to use wide discretionary space accompanied by the absence of public accountability caused the government bureaucracy system provides a fertile ground for corruption. ${ }^{1}$ during this time, the public services made by bureaucratic tendency is seen vulnerable to corruption, therefore public service becomes a strategic point to start the development of good governance in Indonesia. $^{2}$

The efforts to reform the bureaucracy since the administration of President Susilo Bambang Yudhoyono (SBY) contained in Act No. 17 of 2007 on the National LongTerm Development (RPJM Plan of 20052025), namely that the development of the state apparatus is done through bureaucratic reform to improve the professionalism of the state apparatus and to realize good

${ }^{1}$ Suraji. Birokrasi Pemerintah dan kekuasaan di Indonesia, Yogyakarta, Thafa Media, p. 1

${ }^{2}$ Agus Dwiyanto. Mewujudkan good Governance melalui pelaayanan publik, Yogyakarta, Gadjah Mada University Press.p. 20 governance, in the central and local levels to support the success of development in other fields. Implementation of the mandate contained in Government Regulation No. 5 of 2010 on the National Medium-Term Development Plan (RPJMN) of 2010-2014 which states in supporting the realization of Indonesia prosperous, democratic and fair, the development policy in the field of law and apparatus were directed at improving good governance. One of the priorities for implementation is through strengthening the implementation of bureaucratic

reform. ${ }^{3}$

The State Civil Apparatus Commission formation is mandated by article 27 of Law No. 5 of 2014 concerning State Civil Apparatus. $K A S N$ is an answer to the increasing complexity of the modern state which results in the need for fittings or institutions to perform tasks and functions of the state. The previously were executive, legislative or judicial deemed to be inadequate and the existing state apparatus is no longer able to accommodate specific tasks that generally require independence and professionalism in their implementation. Therefore, the formation of equipment or

\footnotetext{
${ }^{3}$ Ibid..p. 16
} 
new institutions is a condition sine qua non for the country's growth. ${ }^{4}$

In the noble goal carried out by the $K A S N$ mentioned above, evidently in reality there was quite a lot of fluctuation when the KASN recommendations went down, this is because in terms of imposing sanctions, the KASN had a weak role and could even be said to be non-existent because based on Article 33 paragraph (1) Law No. 5 of 2014 which states that "in imposing sanctions for Staffing Officers who violate the principles of the Merit System and the provisions of the legislation of KASN authority is limited to recommending". The nature of the recommendations can only be taken into consideration by the President to impose sanctions. ${ }^{5}$ As it is known that the recommendation is interpreted as a conclusion, opinion and suggestion to the reported superior to be implemented and or to be followed up to improve the quality of good government administration. Recommendations also can be interpreted as

\footnotetext{
${ }^{4}$ Hendra Nurtjahjo, (2005), Lembaga, Badan, dan Komisi Negara Independen (State Auxiliary Agencies) di Indonesia: Tinjauan Hukum Tata Negara: Journal of Law and Development, Year of 35 th, No. 3 of July September, Jakarta: Faculty of Law, University of Indonesia, p..277-279,

${ }^{5}$ Yanti Nurmayanti, Kedudukan dan fungsi Komisi Aparatud Sipil Negara (KASN) from: https://www.academia.edu/19348987 accessed on 2nd of April 2017 at 10:00 PM
}

a suggestion (suggestion), but they can also mean advice. Because of its nature as an advice or recommendation then later in practice lead to confusion for local government in implementing, for example, case in Manado. ${ }^{6}$

The Provincial Government of North Sulawesi asked for consideration of the recommendations of $K A S N$ related to the cancellation of position mutation held the provincial government some time ago. According to the Assistant of Commissioner of KASN, Anggara Hayun Anujuprana, mutations that made the provincial government during the last six months could be canceled and officials who had been removed or replaced may return to the starting position.

\section{Identification of Problems}

Starting from the confusion of recommendation implementation that issued, then comes the effort to study theoretically regarding the position of these recommendations of $K A S N$ that seen from a state administration point of view.

\section{B. RESEARCH METHODS}

The research method is a system and a process that absolutely must be done in

\footnotetext{
${ }^{6}$ www.Kasn.go.id//berita media downloaded on 1st of March 2016
} 
the activity of research and development of science. The research aims to reveal the truth systematically, methodologically and certainly. $^{7}$

The kind of research is normative legal research. The normative legal research that is examined is library materials or secondary data that includes primary legal materials, secondary legal materials, and tertiary legal materials. Primary data obtained from the research of literature and documents that are the result of research and treatment of others, which is already available in the form of books or documents that are usually provided in the library or private property as well as laws relating to the problems studied. In the process of analyzed and interpreted data that were collected, the writer did the analysis of the juridical qualitative, ie, after the data is collected then the data is grouped according to each category and then interpreted through words or sentences with frameworks to obtain the conclusion or answer to the question which has been formulated based on the existing legal norms. Primary legal materials gathered by the writer then inventoried and classified

\footnotetext{
${ }^{7}$ Soeejono Soekanto, Sri Mamudji, Penelitian Hukum Normatif Suatu Tinjauan Singkat, Raja Grafindo Persada, 1st edition.printed 14, Jakarta, 2012, p.1.
}

based on the study of documents or under the problems to be discussed.

Those legal materials were studied and understood as the position of KASN as a state institution in the Republic of Indonesia constitutional system and the legal implications on a recommendation that issued. This study was conducted by describing the provisions of the 1945 Constitution and Law No. 5 of 2014 obtained through primary legal materials. Primary legal materials then interpreted grammatically and systemic. The analysis of secondary legal materials in the form of law opinion, journals, legal briefs, articles, websites and then analyzed and described to answer the problem discussed.

\section{RESULTS AND DISCUSSION.}

1. What is the position of $K A S N$ in the constitutional system of the Republic of Indonesia

a. KASN as supporting institutions (State Auxiliary Organs) and as Independent Supervisory Bodies State as an organization of authority/organization of power, therefore the existence of organization in the state is an absolute requirement, and if the state there was no organization it will cause anarchy, which according to Jellinek was a "contradiction in objecto", if the state did 
not have the organs are not in accordance with the nature characteristic. Therefore, in this case, our country encountered any state organ or state scientific equipment. ${ }^{8}$ According to Jellinek's opinion, the understanding of organs is divided into two broad groups namely:

1. Direct state equipment (unmittelbare organ)

2. Indirect state equipment (mittelbare organs)

The direct measurement, according to Jellinek, is whether or not it directly comes from the constitution or vervassung. In the case of direct organs, if there are no organs, then the state does not exist. Furthermore, related to indirect organs always depend on the direct organs. ${ }^{9}$ According to the direct state equipment (Die Saatsorgane), the equipment of the state aims to realize the goals and desires of the state (staatswill). State equipment can be referred to in a variety of terms, namely organs, institutions, agencies, additional institutions (state auxiliaries), independent bodies

8 Padmo Wahjono, Ilmu Negara, IND-HILL-CO, Jakarta, 1999, p. 222

${ }^{9}$ Ibid. (independent state bodies or self-regulatory bodies), state enterprises. ${ }^{10}$

Institutions in terms of their functions are main or primary, and some are secondary or auxiliary. While in terms of hierarchy, the institution can be divided into three layers. The first layer organ can be called a high state institution. The second layer organ is referred to as a state institution, while the third layer organ is a regional institution. Among these institutions, there can be categorized as main or primary organs (primary constitutional organs), and some are supporting or supporting organs (state auxiliary organs/auxiliary institutions). ${ }^{11}$

Among these institutions, there are sometimes also referred to as selfregulatory agencies, independent supervision bodies, or institutions that carry out mixed functions, namely functions of regulative, administrative, and punitive functions which are usually separated but instead carried out simultaneously by these new institutions. ${ }^{12}$

State agencies also have a legal basis in a different formation. The differences in the legal basis of its formation cause a

${ }^{10}$ Hendra Nurtjahjo, Ilmu Negara Pengembangan Teori Bernegara dan Suplemen, Jakarta: PT. RajaGrafindo Persada, 2005), p. 63-64.

${ }^{11}$ Jimly Asshiddiqie, Perkembangan dan Konsolidasi Lembaga Negara Pasca Reformasi, Jakarta: Sinar Grafika, second edition 2012, p vii.

${ }^{12}$ Ibid, P. 7. 
difference in the position of the institution and the degree of the legal treatment of the officials who sat at the institution. At the central level, the establishment of institutions can be divided into four levels: a first, institution established by the Constitution which is a constitutional organ.

This institution is further regulated in the law as a mandate of the Constitution, government regulation, Regulation of the President and the Presidential Decree. The appointment of its members is determined by a Presidential Decree as the highest state administrative official. ${ }^{13}$ The second level of state institutions is an institution established by law that mandates directly from the Constitution ${ }^{14}$ or does not constitute a direct mandate from the Constitution. ${ }^{15}$ Institutions are then formed through this legislation involving the Parliament and the President. Therefore the granting of authority or dissolution and changing the form of these institutions

${ }^{13}$ Ibid.

${ }^{14}$ Examples of institutions set up by the legislation which is the direct mandate of the Constitution is the Election Commission, the Constitutional Court and the Judicial Commission.

${ }^{15}$ Then the state institutions established by law that do not constitute a direct mandate from the Constitution including ASN Commission, the Center for Financial Transaction Reports and Analysis Center (PPATK), the Business Competition Supervisory Commission $(K P P U)$ and the Indonesian Broadcasting Commission $(K P I)$. should involve the role of Parliament and the President. ${ }^{16}$

At the third level are institutions whose source of authority is purely from the president as head of government, therefore the formation is entirely sourced from beleid president (Presidential policy). This means that the formation, change or dissolution depends on the policy of the President alone. Regulations concerning the organization of the relevant state institution are also sufficiently stated in a Presidential Regulation which is regeling and the appointment of its members is made by a Presidential Decree that is beschikking. Then the lower level institutions are those formed based on Ministerial Regulations. Based on the initiative of the minister as a public official, based on the needs related to the government duties and development in the fields which he is responsible may take the form of a body, council, or committees that are not permanent and nature. ${ }^{17}$

$K A S N$ institutions can be categorized as institutions that are not sourced directly from the constitution (derivatives) and as supporting organ (state auxiliary

\footnotetext{
${ }^{16}$ Asshiddiqie, ibid, p 51.

${ }^{17}$ Ibid, p 52.
} 
organs/auxiliary institutions).${ }^{18} \mathrm{KASN}$ is also an independent supervision body. Meanwhile, as an institution that functions to impose penalties, $K A S N$ is only authorized to determine violations of the code of ethics and only has the authority to recommend sanctions. Further will be described below based on the provisions governing

KASN. b. KASN as state auxiliary organs $K A S N$ can be classified into state auxiliary organs, this time in Indonesia known as commissions, state institutions or the like. ${ }^{19}$

The establishment of these institutions, in general, to address all issues in the society which is increasingly complex which cannot be entirely handled by the three main power institutions in the constitution namely executive, legislative and judiciary so that they are expected to be able to help the main state institutions. But the majority of the establishment of supporting institutions due to the distrust towards state institutions by a public that already exist, thus triggering the emergence of new state institutions that act as

\footnotetext{
${ }^{18}$ Ibid, p. vii.

${ }^{19}$ Based on data from the Ministry of Administrative and Bureaucratic Reform, in Indonesia was established 28 non-ministerial government institution $(L P N K)$ and 88 non-structural institutions. Accessed from http://www.menpan.go.id/daftar-kelembagaan
}

supervisor and to take over part of the authority of existing state institutions. Thus the new state institutions are a form of institutional experimentation (institutional experimentation) that can be shaped into council, commission, committee, board, and authority. ${ }^{20}$

KASN received a delegation of authority from the president. Additionally, KASN is one of four institutions associated with the State Civil Apparatus (ASN). Based on Law No. 5 of 2014 Article 25 paragraph (1), the President as the holder of government power is the highest authority in policy, professional development, and $A S N$ Management. Article (2) letter b, to organize the power as referred to in paragraph (1), President delegates part of his power to $K A S N$, relating to the authority to monitor and to evaluate the implementation of $A S N$ 's policies and management to ensure the realization of the Merit System and supervise the application of principles and code of ethics and $A S N$ behavior code. c. $K A S N$ as independent supervisory bodies Based on the mandate of $A S N$ Law, the essence of $A S N^{\prime}$ s commission was formed to support the acceleration of the

20 Lukman Hakim, Kedudukan Hukum Komisi Negara di Indonesia, First Edition (Malang: Equivalent Press, 2010), p. 139 
implementation of bureaucratic reform with a focus on improving $A S N$ management and improving the quality of $A S N$.

Therefore, according to Article 27 of Law Number 5 of 2014, KASN is an independent non-structural institution free from political intervention to create professional and performing $A S N$ employees, provide services fairly and neutrally, and become adhesive and unifier of the nation. Article 30 of $K A S N$ functions to supervise the implementation of basic norms, ethic code and behavior code of $A S N$ as well as the application of the Merit System in ASN's policy and management to government agencies. Also, the duties and authority of $K A S N$ are regulated in Article 31 and Article 32 of the ASN Law.

\section{CLOSING}

a. Conclusion From the whole discussion and analysis that were outlined earlier in this study,

then the writer concludes several important matters related to KASN position in the system of laws and legal effect of the existence of $K A S N$ recommendation to the decision issued by personnel builder officials, among others: 1. That $K A S N$ is an institution that is part of the Republic of Indonesia's state structure, formed as a second layer organ if viewed from the point of hierarchy. The second organ layer is state organs whose source of authority comes from the Constitution or the Law and when viewed from the criteria of function, $K A S N$ is an institution that functions as secondary or supporting. One of the characteristics of supporting organ state (auxiliary state organ) is independent, which is often mentioned by the term as an independent state commission which is idealized to be independent and therefore it is outside the executive, legislative and judicial powers. The basic understanding of the term independent is the existence of freedom, independence, independence, autonomy, not in the power of individuals or institutions. Therefore, there is the implementation of free will or independence that can be realized without any intervention that changes its position to make decisions or policies.

\section{b. Suggestion}

Here are some of the advice given in this study, among others: The existence of KASN as one of the state institutions that concentrate in terms of enforcing $A S N$ management needs to be supported by rules that strengthen the position of Recommendations in the Law on State Civil Apparatus, therefore, it has executive power. 
Things that can be done include: 1. The improvement of quality and quantity of Human Resources needs to be considered because over time there will be more work to be completed by $K A S N$, therefore it is necessary to increase the number of employees and also their competence.

2. Placing the representatives of the State Civil Apparatus Commission in the region as an institution that supervises the application of the merit system in $A S N$ management and policy at Government Agencies, because precisely now in the area the merit system in $A S N$ management cannot be implemented properly.

3. As an independent non-structural institution and free from political intervention, the State Civil Apparatus Commission should be given authority in terms of setting policies on the development of national staffing, therefore in carrying out its role as an institution that can maintain and protect the merit system can be optimally run.

\section{BIBLIOGRAPHY}

Agus Dwiyanto Mewujudkan good Governance melalui pelaayanan publik, Yogyakarta Gadjah Mada University Press.

Hendra Nurtjahjo, Ilmu Negara Pengembangan Teori Bernegara dan Suplemen, Jakarta: PT. RajaGrafindo Persada, 2005)

Hendra Nurtjahjo, (2005), Lembaga, Badan, dan Komisi Negara Independen (State Auxiliary Agencies) di Indonesia: Tinjauan Hukum Tata Negara, Jurnal Hukum dan Pembangunan, Tahun ke-35, Nomor 3 Juli September, Jakarta: Fakultas Hukum Universitas Indonesia,

Jimly Asshiddiqie, Perkembangan dan Konsolidasi Lembaga Negara Pasca Reformasi, Jakarta: Sinar Grafika, cetakan kedua 2012, hal vii.

Lukman Hakim, Kedudukan Hukum Komisi Negara di Indonesia, Cetakan Pertama (Malang: Setara Press, 2010).

Padmo Wahjono, Ilmu Negara, IND-HILLCO,Jakarta, 1999, hal. 222 Suraji.Birokrasi Pemerintah dan kekuasaan di Indonesia, yogyakarta, Thafa Media.

Soerjono Soekanto, dan Sri Mamuji 2012, Penelitian Hukum normatif Suatu Tinjauan Singkat, PT . Raja Grafindo Persada,Jakarta.

Yanti Nurmayanti,Kedudukan dan fungsi Komisi Aparatud Sipil Negara (KASN)

H. Zainuddin Ali, 2009, Metode Penelitian Hukum, Sinar Grafika, Jakarta. 